\title{
Microbiological Quality of Kunnu-Zaki Drinks Sold in Some selected Towns in Osun State, Nigeria
}

\author{
Imoukhuede T. P. ${ }^{1}$, Adepeju A. B. ${ }^{2}$, Akinsuroju M. O. ${ }^{3}$ \\ ${ }^{1}$ Department of Science Laboratory Technology, Faculty of Science, Ekiti State University, Ekiti Nigeria \\ ${ }^{2}$ Department of Food Science and Technology, Joseph Ayo Babalola University, Osun State, Nigeria \\ ${ }^{3}$ Department of Microbiology, Joseph Ayo Babalola University, Osun State, Nigeria \\ Email: teniusng@yahoo.com
}

\begin{abstract}
The microbiological quality of freshly processed and hawked kunnu-zaki drinks, a common Nigerian non-alcoholic beverage was investigated in some selected towns in Osun State, South Western Nigeria. A total of nine (9) towns were assessed. Kunnuzaki drinks were purchased from these towns on twelve different occasions for a period of six month. The samples were microbiologically analyzed using standard methods. pH values ranged from 3.09 - 4.21 in East and West senatorial district. The TTA of the samples ranged from 0.32 - 0.49 in Central and East senatorial district. All the screened drink samples had varying levels of bacterial contamination ranging from $4.2 \times 10^{3}$ to $15.0 \times 10^{3}$ $\mathrm{CFU} / \mathrm{ml}, 4.1 \times 10^{4}$ to $9.6 \times 10^{4} \mathrm{CFU} / \mathrm{ml}$ and $3.5 \times 10^{5}$ to $9.0 \times 10^{5} \mathrm{CFU} / \mathrm{ml}$ for total bacteria, coliform and E. coli count respectively. Total coliform count on MPN ranged from $3 \mathrm{MPN} / \mathrm{ml}$ to $93 \mathrm{MPN} / \mathrm{ml}$. $77.78 \%$ of the total sampled drinks $(n=108)$ that is $(84 / 108)$ had bacteria and fungi count. While all the drinks sampled had total coliform count on MPN exceeding the recommended safe level of zero organisms detectable per 100ml. Seven (7) bacteria species were isolated from the kunnu-zaki drink sampled. The bacteria isolated were Escherichia coli, Bacillus species, Staphylococcus species, Pseudomonas species, Streptococcus specie, Enterobacter species, and Klebsiella species. Fungal count ranged from $3.3 \times 10^{6}$ to $8.0 \times 10^{6} \mathrm{CFU} / \mathrm{ml}$ respectively. Four (4) fungi were also isolated which include Aspergillus fumigatus, Penicilium italicum, Aspergillus niger and Aspergillus flavus. It can therefore be concluded that the presence of these isolated organisms in kunnu-zaki samples analyzed in Osun State could serve as indicator for the need to promote awareness about the possible health hazards that could arise due to the unhygienic ways of handling and processing of the beverage.
\end{abstract}

Keywords- Physico-chemical analysis, Bacteria count, Coliform count (MPN), Fungi count and Frequency of Isolated organisms.

\section{INTRODUCTION}

Beverage is a liquid drink prepared for human consumption (Robert, 2006). The word "beverage" has been derived from the Latin word "bever" meaning rest from work. After work, one tends to feel thirsty due to fluid loss through perspiration and one is inclined to drink water or other potable beverages to compensate fluid loss. Beverages are potable drinks which have thirstquenching, refreshing, stimulating and nourishing qualities (Achi, 2005). By refreshing, one means the replenishment of fluid loss from the body due to perspiration. Nourishment is provided by the nutrients in the beverages, especially fruit juices.

Kunnu-zaki (Millet drink) also referred to as "sweet kunnu-zaki" is a popular traditional and important cereal based, non- alcoholic fermented beverage (Adejuyitan et al., 2008) made from pearl millet (Pennisetum glaucum), maize (Zea mays), or sorghum (Sorghum bicolor), grains but the most commonly used basic ingredient is millet. Maize (Zea mays), millet (Pennisetum glaucum), rice (Oryza sativa) and sorghum (Sorghum bicolor) cereals provide mainly carbohydrates and low quality protein (Steinkraus, 1997). It is generally acceptable and widely consumed throughout Nigeria by children and adults as breakfast drink or food supplements and also a weaning food for infants due to its refreshing qualities most especially in the northern parts and it is consumed throughout the year mostly during dry seasons (Elmahmood and Doughari, 2007). Kunnu-zaki is a refreshing drink usually used to entertain visitors, appetizers and is commonly used or served at social gatherings both rural and urban centers, hawked in the motor parks, school premises and market places (Amusa et al., 2005). It is a staple beverage that is relatively nutritious and affordable when compared to other carbonated and non-carbonated drinks (Adejuyitan et al., 2008). It has low viscosity, a sweet-sour taste depending on the level of fermentation and is milky cream in appearance (Adeyemi and Umar, 1994). It has immense 
social, economic, nutritional and medicinal benefits to most consumers (Akoma et al., 2006). The preparation of locally fermented foods like kunnu-zaki has become a technology in many homes particularly in rural communities and more recently in the urban areas where more women have developed the skill and commercial production which has helped to alleviate poverty amongst the people (Essien et al., 2011).

Kunnu-zaki is been prepared from local cereals which are very common and part of our staple food substances. It is relatively produced in low cost which makes it not expensive because grains and other ingredients used for production are locally sourced and are mostly grown within the savannah region of Nigeria such as Bauchi, Kano, Sokoto and Kastina states (Adebayo et al., 2010) and almost throughout the years, most especially the savannah belt of West Africa and the packaging materials are also available, cheap and easily affordable.

Cereals are grains or edible fruits of the grass-monocot family that may be cultivated and used as foods. In India and Africa, cereals products comprise $80 \%$ or more of the average diet, $50 \%$ in Central and Western Europe and between $20-25 \%$ in the U.S. (Onwueeme and Finha, 1991). Millets are cereal crops or grains for foddler and human food (Ray and Sivakumar, 2009). Millets are in the family of cereals grown globally with differential importance across continents and within regions of the world. It is consumed as staple food and drink in most areas. Across Africa several indigenous foods and drinks are made from flour/meal and malt of millet. They are nutritionally equivalent or superior to other cereals (Obilana and Taylor, 2002). In the Northern area of Nigeria Millet is known as Jero, 'Oka baba' in yoruba land and in America, it is known as milo. It can be stored for 6 months without any significant spoilage. Millet are highly tolerant and are very nutritious containing low phytic acid and are rich in dietary fiber, iron, phosphorus, potassium, magnesium, zinc, thiamine, riboflavin calcium and vitamin $\mathrm{B}$ (niacin, $\mathrm{B}_{6}$ and folic acid) which make millet more superior than most cereals, are now being enhanced through biofortification and micronutrient research (Obilana and Taylor, 2002) which are essential for body growth and development. It is easily digested and gluten-free, an excellent choice for anyone with gluten-intolerance (Oladele and Aina, 2007).

Kunnu-zaki processing is mostly done by women using simple household equipment and utensil depending on cereal availability. Kunnu-zaki is produced from malted millet; a portion of the cereal is malted, dried, ground and then mixed with the uncooked portion. The mixture is then added to the cooked portion and stirred vigorously and allowed to ferment (Akoma et al., 2012). Spices such as ginger (Zingiber officinales), alligator pepper (Afromonium melegueta), red pepper (Capsicum species), black pepper (Piper guineense) and cloves (Syzygium aromaticum) are commonly added to improve flavor and taste while honey, sweet potatoes and sugar are also added to act as a sweetener (Ahmed et al., 2003). The processed kunnu-zaki is usually packed for sale either in nylon or in a plastic container and can also be stored in refrigerators. Some people in some regions prefer it with pepper and sugar while some with little or no pepper and sugar (Adeyemi and Umar, 1994). All these ingredients perform one function or the other in the course of the preparation. The most abundant constituent of kunnu-zaki is water and it acts as the medium in which all other constituents are dissolved and contain only traces amount of inorganic substances. Spices are usually added in small quantities to improve taste and flavor. Because these are agricultural commodities, they may contain a high level of microbial impurities (Adeyemi et al., 1994; Bibek, 2001). The quality and quantity of the products depend largely on the quality of the ingredients and its proper handling in the course of production by the producer. Hence, kunnu-zaki samples for different market in Osun state are purchased to determine the microbial and fungi load.

\section{MATERIALS AND METHODS} STUDY LOCATION

Osun State is located in the South Western part of Nigeria. It covers an area of approximately 14,875 square kilometers, lies between longitude $0400 \mathrm{E}$ and latitude 05 558 and is bounded by Ogun in South, Kwara in North, Oyo in West and Ondo States in the East. It total population is approximately 3,416,959.

\section{COLLECTION AREAS}

Samples were collected and analyzed from nine (9) major markets using Senatorial districts West, East and Central to ensure adequate representation of samples in Osun State Nigeria, which include three (3) popular towns from each Senatorial district. The towns are: Gbongan, Ikire (Sabo market) and Apomu all in Osun West Senatorial districts, Ipetu-Ijesa, Ikeji-Arakeji and Owena-Ijesa all in Osun East Senatorial district, Ada, Ikirun (Oja tuntun) and Ororuwo all in Osun Central Senatorial district.

\section{COLLECTION OF SAMPLES}

Freshly prepared kunnu-zaki samples were purchased in plastic containers (as packaged by the seller) from different Senatorial market locations within Osun State. The samples were labeled and held at $4{ }^{0} \mathrm{C}$ by placing them in refrigerated coolers and conveyed in an ice packed cooler and transported to Microbiology and Biochemistry Department Laboratory of Joseph Ayo Babalola University within three hours (3 hours) of collection for microbiological and physico-chemical analysis respectively. A total of 108 kunnu-zaki drinks samples were purchased and sampled. The period of 
study was six months. All samples were subjected to the same analysis.

\section{PHYSICO-CHEMICAL ANALYSIS OF KUNNU- ZAKI}

The rate of fermentation by each bacterium on the kunnuzaki sample was assessed by testing for $\mathrm{pH}$ and (TTA) Titratable acidity (AOAC, 2005).

\section{DETERMINATION OF pH OF THE SAMPLES}

The $\mathrm{pH}$ of the samples was determined using a laboratory pH meter (Jenway 3015, model 10). The pH was measured by putting $10 \mathrm{ml}$ of the kunnu-zaki into a beaker and readings were taken by dipping the electrode into the kunnu-zaki samples (rinsing out the electrode with distilled water), and measurements taken from the display screen when the readings stabilized (Ofori et al.,1994).

\section{DETERMINATION OF TOTAL TITRATABLE ACIDITY (TTA)}

This is to measure the acidity in a sample. The Total Titratable acidity (TTA) calculated as percentage lactic acid was determined following the method described by (AOAC, 2005).

\section{PROCEDURE}

A $10 \mathrm{ml}$ of kunnu-zaki sample was measured into a dried conical flask, 3 drops of phenolphthalein indicator was added and the flask thoroughly shaken. It was then titrated against $0.1 \mathrm{M} \mathrm{NaOH}$ (Sodium hydroxide) to a pink colour end-point (compared against a white background) and the titre volume was noted and calculated.

\section{DETERMINATION OF MICROBIAL COUNT}

This was carried out using standard microbiological techniques following appropriate dilution on agar plates of Nutrient Agar (NA) for bacteria count, MacConkey Agar (MCA) for coliform count, Eosin Methylene Blue agar (EMB) for E. coli and Potato Dextrose Agar (PDA) for fungi count. The agar media were of oxoid grade using pour plate method (Lateef et al., 2004).

\section{PROCEDURE}

Serial dilution was carried out using $1 \mathrm{ml}$ of kunnu-zaki samples into $9 \mathrm{ml}$ of water. Stocks were prepared in testtubes serially in rows containing $9.0 \mathrm{ml}$ of distilled water representing each sample from each location (APHA, 2001). Then from each suspension $1 \mathrm{ml}$ of dilution was pipette into a set of Petri-dishes and was overlaid with 20 $\mathrm{ml}$ of freshly prepared Nutrient agar (NA), MacConkey (MCA) and Eosin methylene blue (EMB) while others were overlaid with $20 \mathrm{ml}$ of freshly prepared potato dextrose agar (PDA) treated with chloramphenicol (1 per $100 \mathrm{ml}$ ) prior to sterilization. Colonies which develop after incubation for 18 to $24 \mathrm{~h}$ at $37{ }^{\circ} \mathrm{C}$ on the cultured plates were counted using Gallenkamp colony counter and were sub-cultured to obtain pure isolates. The pure isolates were aseptically transferred into Nutrient agar slants and incubated. After $24 \mathrm{~h}$ incubation morphological characterization and biochemical tests were carried out on the isolates to aid identification to genus level on bacteria (Cowan and Steel 1985). The purified fungal isolates were identified on the basis of standard cultural, morphological and microscopic characteristics as described by (Samson et al., 1988). The fungal isolates were sub-cultured on to a sterile fresh media and incubated at room temperature for 3-5 days. Morphological identification was based on colour, textures spreading rate of each colony on the Potato dextrose agar plate.

\section{DETERMINATION OF MOST PROBABLE NUMB ER (MPN)}

The multiple tube method was used to estimate coliform numbers. The presumptive, confirmed and completed test was done by adding varying quantities of kunnu-zaki such as $0.1 \mathrm{ml}, 1.0 \mathrm{ml}$ and $10 \mathrm{ml}$ to varying quantities and strength of MacConkey broth in test tubes containing Durham tube (APHA, 2001). The MPN of coliforms present in the sample was estimated by making reference to McCrady table or probability table (APHA, 2001).

\section{RESULTS AND DISCUSSION}

The results show that the $\mathrm{pH}$ of the samples ranged from $3.09-4.21$ in East and West Senatorial district (Table 1).

The result of the analysis revealed that all samples used have an acidic $\mathrm{pH}$ range of 3.09 - 4.21. The level of acidity of kunnu has been reported by several researchers including Efiuvwevere and Akoma, (1995) and Akoma et al., (2006).

The TTA of the samples ranged from $0.0032-0.0049$ in central and east Senatorial district (Table 2). East Senatorial district had the highest TTA values of kunnuzaki drink in the month of July according to the period of samples collection.

All the kunnu-zaki drinks sampled were contaminated with varying level of bacterial load ranging from $4.2 \times 10^{3}$ to $15.0 \times 10^{3} \mathrm{CFU} / \mathrm{ml}$ in West and East Senatorial district (Table 3). This is in agreement with the findings of Hatcher et al., (1992), Elmamood and Doughari, (2007), Lawal (2012) and Aboh and Oladosu, (2014) who reported a total bacterial count of $5.0 \times 10^{4}$ to $2.0 \times 10^{6}$, $1.0 \times 10^{2}$ to $8.9 \times 10^{4} \mathrm{CFU} / \mathrm{ml}, 5.0 \times 10^{4}$ to $1.79 \times 10^{5}$ $\mathrm{CFU} / \mathrm{ml}$ and $5.1 \times 10^{2}$ to $2.0 \times 10^{8} \mathrm{CFU} / \mathrm{ml}$ respectively. The high bacteria count observed in this study might be attributed to factors such as the environment, which include exposure of the foods (kunun-zaki) to air, soil, type of water used in processing, post production operations and personal hygiene of the handlers (Kawo and Abdulmumin, 2009; Aboloma, 2008). Exposure of the foods to air or dust at the point of sale is likely to increase the counts of the bacteria as virtually most of the 
bacteria are carried in aerosols by dust and air (Karagozlu et al., 2007). Also, during production, most handlers sometime dip their hands into the containers while making kunun-zaki.

The total coliform bacterial count in the kunnu-zaki drink samples using MPN method ranged from $3 \mathrm{MPN} / \mathrm{ml}$ to 43 $\mathrm{MPN} / \mathrm{ml}$ in East, $3 \mathrm{MPN} / \mathrm{ml}$ to $93 \mathrm{MPN} / \mathrm{ml}$ in West and 3 $\mathrm{MPN} / \mathrm{ml}$ to $39 \mathrm{MPN} / \mathrm{ml}$ in Central. All the samples $108 / 108(100 \%)$ of the kunnu-zaki samples examined had coliform count (Table 4). The result shows that West district had the highest total coliform count.

Seven (7) bacteria genera were isolated from the kunnuzaki drink samples. These include Escherichia coli, Pseudomonas species, Staphylococcus species, Enterobacter species, Klebsella species, Streptococcus species and Bacillus species. The detection of S. species was equally isolated by Olasupo et al., (2002) from wara and kunun-zaki, a cereal based, non-alcoholic beverage, also by Aboh and Oladosu, (2014) from kunun-zaki. The presence of organisms like Bacillus species, Streptococcus has been reported by Adeyemi and Umar, (1994) and Ayo, (2004) who also isolated these organisms from kunun-zaki. The presence of Klebsiella species as recorded in this study is usually associated with faecal contamination. Being an enteric bacterium its presence indicates poor practices among handlers. Due to the significance of the faecal-oral route transmission for many bacterial food-borne diseases, basic hygiene measures assume a decisive importance in food safety management (Uzeh et al., 2006). The high occurrence of E. coli $(77.78 \%)$ in kunnu-zaki is an indication of faecal contamination. Ironically, most food handlers do not practice good personal hygiene and do not follow good manufacturing practices, which could reduce the occurrence of such bacteria in foods (Bukar et al., (2009); Kawo and Abdulmumin, (2009)). Egbere et al., (2007) reported the presence of organisms like Bacillus cereus, Staphylococcus aureus and Escherichia coli (PHLS, 1996). It is possible that contamination by these pathogens could have occurred during sieving and packaging, as most of the people involved in the production, packaging and hawking do not take necessary precautions, and as such contamination could be very prominent (Elmamood and Doughari, 2007).Gadaga et al., (2004) reported that pathogens have been isolated from some fermented foods and some laboratory tests have shown the possibility of pathogens to survive and grow in some fermented foods. He said post processing contamination is often cited as the major cause of food poisoning, this agrees with the observation made as regards the source of kunnu collected for this study which is not really hygienic. Gadaga et al., (2004) equally said that Escherichia coli, is the most commonly encountered pathogens in African fermented food. This tally with the types of organism isolated in this study. The occurrence of bacterial pathogens in fermented foods suggests a need for caution in the consumption of this beverage. The source of contamination may also have come from the spices used as additives (Essien et al., 2011 and Lawal, 2012).

Fungal count ranged from $3.3 \times 10^{6}$ to $8.0 \times 10^{6} \mathrm{CFU} / \mathrm{ml}$ in West and Central district (Table 5). A total of Four (4) different moulds were isolated from the kunnu-zaki drink samples in the course of study. These were Aspergillus fumigatus, Penicilium italicum, Aspergillus niger and Aspergillus flavus.

The frequency of occurrence of the organisms isolated from kunnu-zaki drink samples are shown in Table 6 . Escherichia coli and Streptococcus species were found in $77.78 \%(84 / 108)$ of samples examined, Pseudomonas species (33\%), Staphylococcus species (66.67\%), Enterobacter species (55.56\%), Klebsella species (44.44\%), Bacillus species (33.33\%), Aspergillus flavus was found in $77.78 \%(84 / 108)$ of the samples examined, Aspergillus fumigatus (44.44\%), Penicilium italicum (66.67\%) and Aspergillus niger (55.55\%). Aspergillus species is ubiquitous, aerobic fungi that can survive in air, dust. The presence of fungi may be attributed to the acidic nature of the sample since it has been observed that molds are capable of utilizing organic acids. Also the presence of fungi in the food may lead to food poisoning and contaminated fungi result in the production of undesirable odour, colour changes and loss of taste of the sample. The presence of these organisms in the sample may be due to the nutritional composition of the millet; these nutrients are present in different proportions. Aspergillus flavus is a common mold in the environment, and can cause storage problems in stored grains. It can also be a human pathogen, as sociated with Aspergillosis of the lungs and sometimes causing corneal, otomycotic of aflatoxin and nasoorbital infections. Aspergillus flavus spores are allergenic (Klich, 2007). Ijabadeniyi (2007) and Omemu (2011) isolated Penicillium, Aspergillus, Mucor and Rhizopus during the early stage of maize fermentation for ogi production.

The bacterial and fungal counts showed that all the kunnu- zaki sampled had a high prevalence of these contaminants and spoilage organisms which of course is of great concern. They are therefore considered microbiologically unsafe for human consumption when not hygienically prepared and utensils cleaned regularly. Clusters of infection caused by the organisms have been linked to poorly maintained utensils, poor personal hygiene, improper storage facilities, and poor water supply (Oyelana and Coker, 2012). Also it can be linked to unhygienic human handlers, dispensing of the extract into bottles, addition of flavors and sweeteners and process of cooling of the extract (Omemu et al., 2007a). 
Many native African beverages are little known outside the parent continent. Effort should be made to improve in the quality, shelf-life and production process of these indigenous beverages so that large-scale production for export outside the continent can be carried out. Many people now prefer imported and exotic beverages because of their attractive form, long shelf life, ease of transportation and other forms of utility which consumers associate with them (Achi, 2005). As of now, there are no industries involved in production of Kunnu-zaki. Kunnuzaki is widely believed to be of immense social, economic and medicinal importance to its numerous consumers (Akoma et al., 2006).

Table.1: pH Values of Kunnu-zaki Drink Sampled from Some Selected Towns in Osun State.

pH VALUES

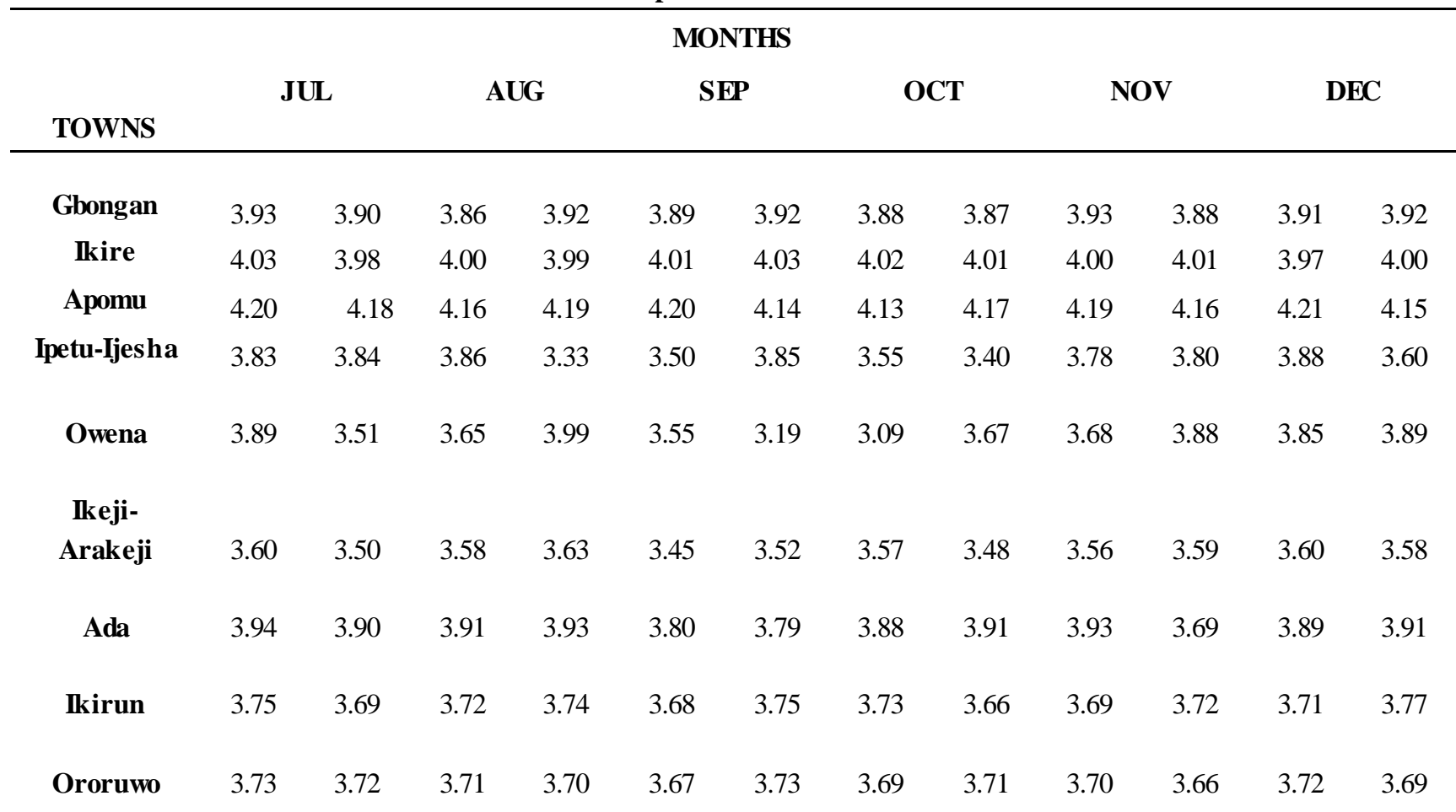

Table.2: Total Titratable Acidity Values for Kunnu-zaki Drink Sampled from Some Selected Towns in Osun State.

TITRABLE ACIDITY VALUES

\begin{tabular}{|c|c|c|c|c|c|c|c|c|c|c|c|c|}
\hline \multicolumn{13}{|c|}{ MONTHS } \\
\hline TOWNS & \multicolumn{2}{|c|}{ JUL } & \multicolumn{2}{|c|}{ AUG } & \multicolumn{2}{|c|}{ SEP } & \multicolumn{2}{|c|}{ OCT } & \multicolumn{2}{|c|}{ NOV } & \multicolumn{2}{|c|}{ DEC } \\
\hline Gbongan & 0.0038 & 0.0041 & 0.0036 & 0.0038 & 0.0039 & 0.0037 & 0.0035 & 0.0040 & 0.0039 & 0.0037 & 0.0039 & 0.0041 \\
\hline Ikire & 0.0036 & 0.0040 & 0.0042 & 0.0037 & 0.0041 & 0.0041 & 0.0039 & 0.0036 & 0.0038 & 0.0040 & 0.0033 & 0.0037 \\
\hline Apomu & 0.0035 & 0.0038 & 0.0039 & 0.0036 & 0.0038 & 0.0036 & 0.0040 & 0.0038 & 0.0041 & 0.0041 & 0.0038 & 0.0036 \\
\hline $\begin{array}{l}\text { Ipetu- } \\
\text { Ijesha }\end{array}$ & 0.0037 & 0.0041 & 0.0043 & 0.0039 & 0.0040 & 0.0038 & 0.0039 & 0.0041 & 0.0038 & 0.0037 & 0.0035 & 0.0039 \\
\hline Owena & 0.0049 & 0.0047 & 0.0037 & 0.0040 & 0.0038 & 0.0036 & 0.0037 & 0.0038 & 0.0037 & 0.0039 & 0.0040 & 0.0038 \\
\hline $\begin{array}{l}\text { Ikeji- } \\
\text { Arakeji }\end{array}$ & 0.0040 & 0.0039 & 0.0038 & 0.0041 & 0.0036 & 0.0038 & 0.0037 & 0.0034 & 0.0041 & 0.0040 & 0.0039 & 0.0038 \\
\hline Ada & 0.0037 & 0.0045 & 0.0038 & 0.0038 & 0.0039 & 0.0039 & 0.0037 & 0.0038 & 0.0039 & 0.0041 & 0.0040 & 0.0041 \\
\hline Ikirun & 0.0036 & 0.0038 & 0.0040 & 0.0040 & 0.0041 & 0.0039 & 0.0032 & 0.0037 & 0.0044 & 0.0040 & 0.0039 & 0.0041 \\
\hline Ororuwo & 0.0039 & 0.0041 & 0.0037 & 0.0039 & 0.0038 & 0.0040 & 0.0036 & 0.0041 & 0.0040 & 0.0039 & 0.0039 & 0.0038 \\
\hline
\end{tabular}




\section{BACTERIAL COUNT (CFU/ml)}

\section{MONTHS}

JUL

AUG

SEP

OCT

NOV

DEC

TOWNS

$\begin{array}{llllllllllll}9.7 & 9.0 & 8.2 & 9.5 & 4.2 & 8.0 & 7.9 & 7.5 & 8.4 & 8.6 & 6.5 & 7.0\end{array}$

Gbongan $\quad \times 10^{3} \times 10^{3} \quad \times 10^{3} \quad \times 10^{3} \quad \times 10^{3} \quad \times 10^{3} \quad \times 10^{3} \quad \times 10^{3} \quad \times 10^{3} \quad \times 10^{3} \quad \times 10^{3} \quad \times 10^{3}$

$\begin{array}{llllllllllll}6.5 & 7.0 & 7.5 & 8.0 & 8.0 & 9.0 & 7.6 & 9.2 & 9.3 & 8.8 & 10.0 & 9.5\end{array}$

Ikire $\quad \times 10^{3} \times 10^{3} \quad \times 10^{3} \quad \times 10^{3} \quad \times 10^{3} \quad \times 10^{3} \quad \times 10^{3} \quad \times 10^{3} \quad \times 10^{3} \quad \times 10^{3} \quad \times 10^{3} \quad \times 10^{3}$

$\begin{array}{lllllllllllll} & 8.0 & 8.8 & 8.0 & 9.1 & 9.6 & 8.9 & 7.3 & 7.4 & 6.0 & 9.2 & 8.5 & 6.4 \\ \text { Apomu } & \times 10^{3} & \times 10^{3} & \times 10^{3} & \times 10^{3} & \times 10^{3} & \times 10^{3} & \times 10^{3} & \times 10^{3} & \times 10^{3} & \times 10^{3} & \times 10^{3} & \times 10^{3}\end{array}$

$\begin{array}{lllllllllllll}\text { Ipetu- } & 6.6 & 7.8 & 6.8 & 6.1 & 9.5 & 7.4 & 8.6 & 6.6 & 8.8 & 9.3 & 7.7 & 8.1\end{array}$

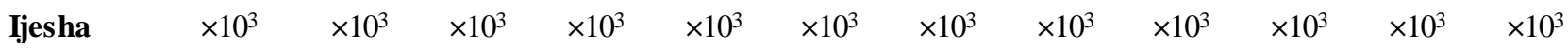

$\begin{array}{llllllllllll}15.0 & 6.1 & 5.3 & 4.9 & 7.6 & 9.7 & 6.0 & 7.1 & 6.6 & 9.1 & 5.5 & 7.1\end{array}$

Owena $\quad \times 10^{3} \times 10^{3} \times 10^{3} \quad \times 10^{3} \quad \times 10^{3} \quad \times 10^{3} \quad \times 10^{3} \quad \times 10^{3} \quad \times 10^{3} \quad \times 10^{3} \quad \times 10^{3} \quad \times 10^{3}$

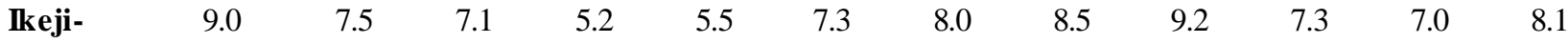

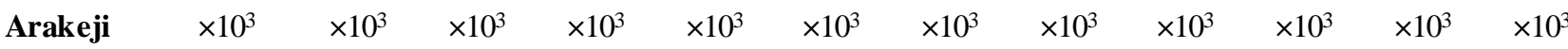

\begin{tabular}{lllllllllllll}
\multirow{2}{*}{ Ada } & 6.6 & 4.7 & 8.2 & 6.7 & 7.3 & 8.4 & 6.6 & 9.1 & 7.5 & 6.2 & 7.5 & 7.5 \\
& $\times 10^{3}$ & $\times 10^{3}$ & $\times 10^{3}$ & $\times 10^{3}$ & $\times 10^{3}$ & $\times 10^{3}$ & $\times 10^{3}$ & $\times 10^{3}$ & $\times 10^{3}$ & $\times 10^{3}$ & $\times 10^{3}$ & $\times 10^{3}$ \\
\multirow{3}{*}{ Ikirun } & 10.0 & 8.2 & 8.3 & 9.9 & 5.0 & 8.9 & 9.5 & 9.0 & 8.1 & 9.7 & 6.0 & 9.1 \\
& $\times 10^{3}$ & $\times 10^{3}$ & $\times 10^{3}$ & $\times 10^{3}$ & $\times 10^{3}$ & $\times 10^{3}$ & $\times 10^{3}$ & $\times 10^{3}$ & $\times 10^{3}$ & $\times 10^{3}$ & $\times 10^{3}$ & $\times 10^{3}$ \\
& 7.5 & 9.1 & 8.6 & 9.5 & 8.0 & 7.2 & 9.5 & 7.1 & 7.2 & 6.7 & 9.0 & 6.2 \\
Ororuwo & $\times 10^{3}$ & $\times 10^{3}$ & $\times 10^{3}$ & $\times 10^{3}$ & $\times 10^{3}$ & $\times 10^{3}$ & $\times 10^{3}$ & $\times 10^{3}$ & $\times 10^{3}$ & $\times 10^{3}$ & $\times 10^{3}$ & $\times 10^{3}$
\end{tabular}

Table.4: Coliform Count (MPN McCredy or Probability Table) of Kunnu-zaki Drink Sampled from Some Selected Towns in Osun State.

COLIFORM COUNT MPN/ml

\begin{tabular}{|c|c|c|c|c|c|c|c|c|c|c|c|c|}
\hline \multicolumn{13}{|c|}{ MONTHS } \\
\hline TOWNS & \multicolumn{2}{|c|}{ JUL } & \multicolumn{2}{|r|}{ AUG } & \multicolumn{2}{|c|}{ SEP } & \multicolumn{2}{|c|}{ OCT } & \multicolumn{2}{|c|}{ NOV } & \multicolumn{2}{|r|}{ DEC } \\
\hline Gbongan & 9 & 3 & 7 & 3 & 3 & 43 & 11 & 28 & 75 & 93 & 3 & 4 \\
\hline Ikire & 20 & 43 & 28 & 21 & 20 & 39 & 3 & 23 & 4 & 23 & 13 & 11 \\
\hline Apomu & 7 & 3 & 4 & 7 & 7 & 4 & 3 & 11 & 9 & 11 & 23 & 28 \\
\hline Ipetu-Ijesha & 11 & 23 & 21 & 7 & 3 & 4 & 4 & 20 & 28 & 43 & 3 & 3 \\
\hline Owena & 4 & 7 & 4 & 11 & 13 & 3 & 21 & 21 & 28 & 3 & 4 & 7 \\
\hline Ikeji & 11 & 21 & 13 & 7 & 4 & 3 & 7 & 20 & 11 & 43 & 28 & 39 \\
\hline Ada & 3 & 4 & 11 & 9 & 20 & 21 & 4 & 3 & 7 & 7 & 3 & 3 \\
\hline Ikirun & 7 & 9 & 13 & 4 & 3 & 11 & 21 & 11 & 13 & 3 & 4 & 4 \\
\hline Ororuwo & 3 & 4 & 11 & 39 & 13 & 9 & 3 & 11 & 39 & 4 & 11 & 3 \\
\hline
\end{tabular}

Legend:

MPN= (Most Probable Number) 
FUNGI COUNTS (SFU/ml)

\begin{tabular}{|c|c|c|c|c|c|c|c|c|c|c|c|c|}
\hline \multirow{2}{*}{$\begin{array}{l}\text { MONTHS } \\
\text { TOWNS }\end{array}$} & \multicolumn{2}{|c|}{ JUL } & \multicolumn{2}{|c|}{ AUG } & \multicolumn{2}{|c|}{ SEP } & \multicolumn{2}{|c|}{ OCT } & \multicolumn{2}{|c|}{ NOV } & \multicolumn{2}{|c|}{ DEC } \\
\hline & & & & & & & & & & & & \\
\hline & 4.5 & 5.0 & 3.3 & 6.5 & 4.0 & 5.0 & 4.1 & 4.3 & 6.0 & 4.7 & 5.1 & 4.6 \\
\hline \multirow[t]{2}{*}{ Gbongan } & $\times 10^{6}$ & $\times 10^{6}$ & $\times 10^{6}$ & $\times 10^{6}$ & $\times 10^{6}$ & $\times 10^{6}$ & $\times 10^{6}$ & $\times 10^{6}$ & $\times 10^{6}$ & $\times 10^{6}$ & $\times 10^{6}$ & $\times 10^{6}$ \\
\hline & 4.2 & 5.8 & 3.3 & 5.9 & 5.0 & 6.0 & 5.7 & 6.7 & 6.9 & 6.4 & 5.0 & 6.0 \\
\hline \multirow[t]{2}{*}{ Ikire } & $\times 10^{6}$ & $\times 10^{6}$ & $\times 10^{6}$ & $\times 10^{6}$ & $\times 10^{6}$ & $\times 10^{6}$ & $\times 10^{6}$ & $\times 10^{6}$ & $\times 10^{6}$ & $\times 10^{6}$ & $\times 10^{6}$ & $\times 10^{6}$ \\
\hline & 5.0 & 4.7 & 6.0 & 6.8 & 6.9 & 5.6 & 5.0 & 5.2 & 6.3 & 7.8 & 6.5 & 5.8 \\
\hline Apomu & $\times 10^{6}$ & $\times 10^{6}$ & $\times 10^{6}$ & $\times 10^{6}$ & $\times 10^{6}$ & $\times 10^{6}$ & $\times 10^{6}$ & $\times 10^{6}$ & $\times 10^{6}$ & $\times 10^{6}$ & $\times 10^{6}$ & $\times 10^{6}$ \\
\hline Ipetu- & 3.9 & 5.8 & 4.6 & 4.0 & 7.6 & 4.8 & 7.0 & 5.0 & 5.8 & 5.0 & 4.9 & 5.5 \\
\hline \multirow[t]{2}{*}{ Ijesha } & $\times 10^{6}$ & $\times 10^{6}$ & $\times 10^{6}$ & $\times 10^{6}$ & $\times 10^{6}$ & $\times 10^{6}$ & $\times 10^{6}$ & $\times 10^{6}$ & $\times 10^{6}$ & $\times 10^{6}$ & $\times 10^{6}$ & $\times 10^{6}$ \\
\hline & 4.8 & 4.3 & 4.2 & 3.8 & 6.0 & 6.8 & 4.1 & 5.3 & 5.0 & 6.4 & 4.2 & 5.9 \\
\hline Owena & $\times 10^{6}$ & $\times 10^{6}$ & $\times 10^{6}$ & $\times 10^{6}$ & $\times 10^{6}$ & $\times 10^{6}$ & $\times 10^{6}$ & $\times 10^{6}$ & $\times 10^{6}$ & $\times 10^{6}$ & $\times 10^{6}$ & $\times 10^{6}$ \\
\hline Ikeji- & 4.9 & 6.4 & 5.8 & 4.0 & 3.5 & 5.1 & 6.3 & 6.0 & 4.9 & 5.8 & 4.9 & 6.0 \\
\hline \multirow[t]{2}{*}{ Arakeji } & $\times 10^{6}$ & $\times 10^{6}$ & $\times 10^{6}$ & $\times 10^{6}$ & $\times 10^{6}$ & $\times 10^{6}$ & $\times 10^{6}$ & $X 10^{6}$ & $\mathrm{X} 10^{6}$ & $\times 10^{6}$ & $\times 10^{6}$ & $\times 10^{6}$ \\
\hline & 5.3 & 3.8 & 6.0 & 5.8 & 6.0 & 5.8 & 4.8 & 6.1 & 5.7 & 4.9 & 6.0 & 5.3 \\
\hline \multirow[t]{2}{*}{ Ada } & $\times 10^{6}$ & $\times 10^{6}$ & $\times 10^{6}$ & $\times 10^{6}$ & $\times 10^{6}$ & $\times 10^{6}$ & $\times 10^{6}$ & $\times 10^{6}$ & $\times 10^{6}$ & $\times 10^{6}$ & $\times 10^{6}$ & $\times 10^{6}$ \\
\hline & 5.0 & 5.9 & 5.1 & 8.0 & 4.3 & 6.9 & 5.7 & 4.6 & 6.0 & 6.5 & 4.5 & 7.0 \\
\hline \multirow[t]{2}{*}{ Ikirun } & $\times 10^{6}$ & $\times 10^{6}$ & $\times 10^{6}$ & $\times 10^{6}$ & $\times 10^{6}$ & $\times 10^{6}$ & $\times 10^{6}$ & $\times 10^{6}$ & $\times 10^{6}$ & $\times 10^{6}$ & $\times 10^{6}$ & $\times 10^{6}$ \\
\hline & 6.0 & 5.7 & 5.5 & 5.9 & 5.5 & 5.8 & 7.9 & 5.5 & 5.0 & 4.8 & 6.5 & 5.0 \\
\hline Ororuwo & $\times 10^{6}$ & $\times 10^{6}$ & $\times 10^{6}$ & $\times 10^{6}$ & $\times 10^{6}$ & $\times 10^{6}$ & $\times 10^{6}$ & $\times 10^{6}$ & $\times 10^{6}$ & $\times 10^{6}$ & $\times 10^{6}$ & $\times 10^{6}$ \\
\hline
\end{tabular}

\section{Legend:}

$\mathrm{Sfu} / \mathrm{ml}=$ Spore forming unit per $\mathrm{ml}$

Table.6: Frequency of Occurrence of Organisms Isolated From Kunnu-Zaki Drink Sample From Some Selected Towns in Osun State.

\begin{tabular}{|c|c|c|c|c|c|c|c|c|c|c|}
\hline Isolates & Gbongan & Ikire & Apomu & Ipetu & Owena & Ikeji & Ada & Ikirun & Ororuwo & $\begin{array}{l}\% \\
\text { Occurrence }\end{array}$ \\
\hline $\begin{array}{l}\text { Pseudomonas } \\
\text { species }\end{array}$ & - & + & - & - & + & + & - & - & - & 33.33 \\
\hline Bacillus species & - & - & + & - & + & - & + & - & - & 33.33 \\
\hline $\begin{array}{l}\text { Klebsiella species } \\
\text { Aspergillus }\end{array}$ & - & + & + & - & + & + & - & - & - & 44.44 \\
\hline fumigates & - & - & - & + & + & + & - & + & - & 44.44 \\
\hline Aspergillus Niger & + & + & + & - & + & - & - & + & - & 55.55 \\
\hline Enterobacter species & + & + & - & + & - & - & - & + & + & 55.56 \\
\hline $\begin{array}{l}\text { Staphylococcus } \\
\text { species }\end{array}$ & + & - & + & - & + & + & - & + & + & 66.67 \\
\hline Penicilium italicum & + & - & + & - & + & + & + & + & - & 66.67 \\
\hline Escherichia coli & + & + & + & + & + & - & + & + & - & 77.78 \\
\hline
\end{tabular}




\begin{tabular}{|c|c|c|c|c|c|c|c|c|c|c|}
\hline $\begin{array}{l}\text { Streptococcus } \\
\text { species }\end{array}$ & - & + & + & + & - & + & + & + & + & 77.78 \\
\hline Aspergillus flavus & + & + & + & + & + & - & + & - & + & 77.78 \\
\hline
\end{tabular}

\section{CONCLUSION}

It is well known that kunnu-zaki is one of the locally made beverages that people purchase regularly for its cheap cost, sweet taste and its nutritional values. The presence of these isolated organisms in kunnu-zaki samples analyzed in Osun State could serve as indicator for the need to promote awareness about the possible health hazards that could arise due to handling and processing of the beverage. The range of microorganism isolated pose serious threat to food safety and hence the need to ensure microbial safety during the production and distribution of this drink that is widely consumed in some towns in Osun State, Nigeria.

\section{REFERENCES}

[1] Aboh, M. I., Oladosu, P. (2014). Microbiological assessment of kunun-zaki marketed in Abuja municipal area council (AMAC) in Federal Capital Territory (FCT), Nigeria. African Journal Microbiology Resource, 8 (15): 1633 - 1637.

[2] Aboloma, R. I. (2008). Microbiological analysis of bread samples from bakery to sale - point in Ado Ekiti, Ekiti State, Nigeria. Biology Environmental Science Journal Tropical, 5 (3): 77 - 81.

[3] Achi, O. K. (2005). The potential for upgrading traditional fermented foods through biotechnology. African Journal of Biotechnology, 4 (5): 375 - 380.

[4] Adejuyitan, J. A., Adelakun, O. E., Olaniyan, S. A. and Popoola, F. I. (2008). Evaluating the quality characteristics of kunu produced by dry-milled sorghum. African Journal of Biotechnology, 7 (13): $2244-2247$.

[5] Adeyemi, I. A. and Umar, S. (1994). Effect of manufacture on quality characteristics of kunu-zaki, a millet based beverage. Nigeria Food Journal, 12: 34 40.

[6] Akoma, O., Agarry, O. O. and Nkama, I. (2013). A study on the production and consumption pattern of Kunun-zaki: A cereal based ethnic fermented beverage of Northern Nigeria. British Journal Applied Science Technology, 3: 1220 - 1227.

[7] Amusa, N. A. and Ashaye, O. A. (2009). Effect of processing on nutritional, microbiological and sensory properties of kunun-zaki (a sorghum based non- alcoholic beverage) widely consumed in Nigeria. Pakistan Journal Nutrition, 8 (3): 288 - 292.

[8] AOAC. (2005). Association of official analytical chemists. Official methods of analysis (22nd edition). Washington D. C, USA, 1 (5): 115 - 119.

[9] APHA. (2001). Compendium of methods for the microbiological examination of foods, 4th edition, F. L. Downes and K, Ito (editions), American public health association, Washington, D. C., 34 - 170.

[10] Ayo, J. A. (2004). Microbiological evaluation of "kunun-zaki" and "zoborodo" drink (beverages) locally produced and sold in a polytechnic community in Nigeria. Nigeria Food Journal 22: 119 - 126.

[11] Egbere, O. J., Adik, C., Inyang, C. U., Henry, U. I. and Ogbonna, C. I. C. (2007). Microorganisms as sociated with fermentation and spoilage of kunun zaki. Nigeria Journal of Biotechnology, 18 (1-2): 49 - 55.

[12] Elmahmood, A. M. and Doughari J. H. (2007). Microbial quality assessment of kunnu-zaki beverages sold in Girei town of Adamawa State, Nigeria. African Journal Science, 1: $011-015$.

[13] Essien, E., Monago, C., and Edor, E. A. (2011). Evaluation of the nutritional and microbiological quality of kunun (a cereal based non-alcoholic beverage) in Rivers State, Nigeria. The Internet Journal of Nutrition and Wellness, 10 (2).

[14] Gadaga, T. H., Nyanga, L. K. and Mutukumira, A. N. (2004). The occurrence, growth and control of pathogens in African fermented food. African Journal of Food Agriculture Nutrition and Development, 4: $5358-5374$.

[15] Ijabadeniyi, A. O. (2007). Microbiological safety of garri, lafun and ogiri in Akure metropolis, Nigeria. African Journal of Biotechnology, 6 (22): 2633 - 2635.

[16] Klich, M. A. (2007). Aspergillus flavus: the major producer of Aflatoxin. Molecular Plant Pathology, 8 (6): $713-722$. 